\title{
A Research to Integrate Baoding Red Culture into College English Teaching
}

\author{
Chen Guan, Huijun Fu, Yan Liu \\ College of Foreign Languages Education and International Business, Baoding University, Baoding, China \\ Email: guanchen_1981@163.com, 496472980qq.com, 406068102@qq.com
}

How to cite this paper: Guan, C., Fu, H. J., \& Liu, Y. (2021). A Research to Integrate Baoding Red Culture into College English Teaching. Creative Education, 12, 618-624. https://doi.org/10.4236/ce.2021.123042

Received: February 20, 2020

Accepted: March 22, 2021

Published: March 25, 2021

Copyright $\odot 2021$ by author(s) and Scientific Research Publishing Inc. This work is licensed under the Creative Commons Attribution International License (CC BY 4.0).

http://creativecommons.org/licenses/by/4.0/

\section{Open Access}

\begin{abstract}
As the Chinese people's precious cultural heritage, the red culture deserves the Chinese younger generation's worship and inheritance. However, current college English teaching doesn't play a positive role in the inheritance of Chinese red culture. This paper takes red culture education in Baoding district as an example, discusses the significance of introducing red culture into college English teaching, presents the current problems of the integration of red culture into college English teaching, and finally puts forward countermeasures to the above-mentioned problems. Hopefully, this paper can provide some insight into how to effectively integrate red culture into college English teaching.
\end{abstract}

\section{Keywords}

Baoding Red Culture, College English Teaching, Integration

\section{Introduction}

Red culture is Chinese people's precious cultural heritage forged in revolutionary war era, carrying rich revolutionary spirit and profound cultural connotation. Baoding, located in the middle of Hebei province, has a long history and splendid culture. In modern times, it was the core area of Jinchaji District Anti-Japanese Revolutionary Base Area and the main anti-Japanese battlefield in North China. Baoding is blessed with rich red culture resources. The Site of Tunnel Warfare in Ranzhuang, the Work-and-study in France Program Museum, the Monument of Five Heroes on Langya Mountain are representatives of Baoding red culture. These valuable cultural heritages are worthy of further understanding, inheritance and promotion by contemporary college students.

However, the current college English teaching focuses on a pure training of 
language skills and the introduction of Western literature and culture. Red culture, as an important part of Chinese culture, hasn't been attached enough attention to it deserves. The purpose of this paper is to highlight the significance of introducing red culture into college English teaching, to present the current situation of integration of red culture into English teaching and to put forward some countermeasures of how to effectively implement red culture education in English class.

\section{The Significance of Red Culture}

The General Secretary Xi Jinping advocated strengthening students' ideological and political education. Red culture is a good way to achieve the goal. Teenagers are in an important stage of the formation of life values, so red culture plays an important role in cultivating the spirit and quality of patriotism, hardship and simplicity, and willingness to contribute. $\mathrm{Xi}$ pointed out that we should carry forward the advantages of red resources and pass on the red gene from generation to generation (Ding, 2018). Every red tourist attraction is a lively classroom, which is constantly learning, and contains rich political wisdom and moral nourishment (Zhao, 2015). By reading red culture literate works, visiting revolutionary sites, etc, college students can be immersed in the situation and be touched physically and mentally, and then establish a correct world outlook.

What's more, red culture is to prosper the socialist culture with Chinese characteristics and enhance the cultural confidence of our people (Tan, 2014). As a part of the excellent traditional culture of the Chinese nation, red culture injects vitality into the spirit of the Chinese nation and becomes an important part of the advanced socialist culture (Huo, 2017). Red culture contains the excellent gene of Chinese cultural self-confidence. Witnessing the rejuvenation of our motherland, the younger generation of China should build up their personality by absorbing the perseverance, struggling and self-reliance which are the precious value of red culture. And they can proudly show our Chinese culture to the world. Therefore, to enhance the cultural confidence of the Chinese people is inseparable from the inheritance and promotion of red culture.

\section{The Current Situation of the Integration of Baoding Red Culture Education into College English Teaching}

In order to accurately investigate the situation of the integration of red culture into college English teaching, the research was carried out in four universities or colleges in Baoding. They are Hebei University, Hebei Agriculture University, Baoding University and Baoding Vocational \& Technical College. 300 subjects participated in this investigation, majoring in Chinese language and literature, preschool education, landscape design, biochemical technology, and marketing respectively. They are from Grade 1 to 3 of the above-mentioned schools with the ratio of male to female basically balanced. Some of the students received the interview after the questionnaire. Totally, 300 copies of questionnaire were dis- 
tributed and 295 valid were recollected. Besides, 20 college English teachers are invited to participate in this investigation and received the interview.

The result of the investigation is not satisfactory. Generally speaking, there are three major problems: 1) teachers and students' weak political literacy; 2) output motivation deficiency; 3) unscientific evaluation criteria.

Most of the interviewees of the investigation, both teachers and students, know the term "red culture", but as for the connotation of this term, few of them can give a clear explanation. They frankly admit that they know the significance of red culture but rarely connect red culture with their daily life. The teachers who received the interview tell the truth, that it, college English teachers are pushed to finish teaching tasks within limited time. It seems to be impossible for them to have red culture teaching in their class. And the teaching material deficiency is a problem too. English materials of red culture that are suitable for students are not available at hand.

The shortage of learning and output motivation is also a problem for students. They think they seldom have the opportunity to talk about red culture in English. If the chance of practical usage is slim, why should they learn it?

At present, the assessment of college English teaching is still greatly affected by exam-oriented practice. It's quite common that the final examination scores usually determine the assessment of a student's. The assessment way is single, the content is incomplete, and the method is unscientific. The test mainly focuses on language knowledge in textbook, and does not take the practical usage for local cultural development into account.

\section{Countermeasures and Suggestions}

As discussed in the previous section, there are some deficiencies in college English teaching, such as skill-training overwhelms content-exploration, input overwhelms output, and attachment to foreign culture overwhelms Chinese traditional culture. Cross-cultural education requires bidirectional. Therefore, the majority of English teachers should try their best to explore the effective strategies to highlight the significance of red culture and help students to immerse themselves in the sea of red culture and absorb the virtue and value of red culture factors, finally advocate red culture in English.

First, strengthening the teachers' and students' awareness of red culture. English teachers should establish a correct outlook on English education and national culture by improving their own local cultural literacy and national cultural awareness, so as to make English teaching into English education, and create English classroom as an important position to enhance students' national spirit. To be specific, it is recommended for English teacher to read more documents and literary works about Baoding red culture, such as Red Flag Pedigree (Hong Qi $P u$, Liang Bin), Lotus Lake (He Hua Dian, Sun Li). Teachers can select some typical materials which are excellent examples of Baoding red culture and translate them into English. In the process of translation, teachers should take stu- 
dents' current ability into consideration, that is to say, the selection of words and sentence structures should be suitable for students' competence. Some questions based on the English translation are to be designed which can trigger students' thinking. These English materials about Baoding red culture enable students to get more access to Baoding red culture and meanwhile know how to tell the red stories in English. As a result, both language teaching and content teaching can be achieved. As for the problem of how to get connected with red culture in students' daily life, the following suggestions worth a try. At present, many universities take the revolutionary sites as the ideological and political education base. By visiting the revolutionary sites, college students can be immersed in the situation and be touched physically and mentally. Another way is to invite students to watch red culture films, documents or talk shows. Then the students get together and share their opinions after watching. These measures may help students to establish a correct world outlook.

Secondly, producing more output by providing more stimulus. Output motivation deficiency may be caused by the lack of real environment stimulus. In traditional face-to-face English class, a lot of input activities occupy the majority of time. Without the sense of achievement made by practical output, students can't see the necessity of learning. Building up an efficient culture classroom and increasing students' output under the guidance of POA is one of the solutions. Step 1, the teacher sets up scenario and assigns the initial output task to students. The more specific the task is, the better. Don't forget that the task shouldn't be too hard for students. Step 2, the students try to make the output for the first time, and they find out the gap between what he is expected to do and what he can do by now in the process of output trial. Step 3, according to the gap, the teacher scaffolds students to make up for the lack and promote the output by providing more targeted input. For example, the teacher gives students the following scenario: A group of overseas students are going to visit the Site of Tunnel Warfare in Ranzhuang. As their tour guide, you are expected to introduce the history and characteristics of this site. Please prepare the tour guide presentation. In this process of preparation, the students may come across some difficulties, such as some unfamiliar terms as “人防工事”、“双向地道”、“卡口”, etc. Besides, the presentation should be logically arranged, from the outside look to the inside facilities, from high to low in the tunnel. With the definite goal of solving the above problems, the students become quite clear about their gap. During the class, the teacher invites the students to watch the video-clip of the film Tunnel War to help them know more about the tunnel. And then with reading material about The Site of Tunnel Warfare in Ranzhuang, the students pay special attention to the specific terms and structure arrangement. The teacher asks the students about the thing of the tunnel that most interests them, because the thing they are interested in may also be the same attraction for the foreign visitors. Then think about how to depict it vividly. These several during-class activities can narrow the gap down. The students can have a try of the 
output for the second time. Finally, evaluation made by the student himself, the teacher and the peer can enhance the output effect. By doing so, the dual goals of language learning and red culture education can be achieved, and students' English expression ability in terms of Baoding red culture can be expected.

Thirdly, implementing various ways of input strategies to promote output, and ensuring effective output with the use of evaluation system. 1) The teachers need to collect and integrate Baoding red culture resources into English teaching in many ways. For the problem that English materials of Baoding red culture are in kind of shortage, the teachers are suggested to work together to translate Baoding red culture into English version and adapt them to be suitable for students' level, so that Baoding red culture materials in English are organized systematically. 2) Through the way of supplement, extension or sublimation, the content of red culture is integrated into the unit theme of the textbook to complement the input. The teachers play the key role of combining the red culture with the curriculum, getting the red culture naturally connected with the unit theme of the textbook. 3) English class could be both interesting and productive as long as the students are involved in different practical activities, for example, collecting theme-related materials, making PPT, drama play, etc. For one thing, it is good for the cultivation of students' autonomous-learning ability; for another, it can promote students' output.

Fourthly, innovating the assessment form and criteria. The current assessment which is characterized by western culture input and final examination should be changed into a multiple assessment system. The students can be offered with multiple learning patterns including "in-class \& off-class", "on-campus \& off-campus", "teacher's presentation \& students' autonomous learning". Off-class and online platform can free teachers' tight schedule in class. Some videos of red culture performed and shot by students can be uploaded to online platform and evaluated by different parties. The scores made by the different participants (teacher, individual, peer) at different times should be taken into consideration when the assessment is made. The test for English skills should shift priority to content-based evaluation. In other words, content itself and the idea expressed through the content should be attached great importance. Take the guide presentation of the Site of Tunnel Warfare in Ranzhuang as an example, the students' performance should be evaluated from different perspectives. Content is the first evaluation item. Whether the students have introduced the history and the most distinctive characteristics of the site clearly and logically is the primary evaluation criterion. Then it comes to English skills, including the accuracy and fluentness of pronunciation, the selection of words, etc. Last but not least, the overall performance effect of the student should be one of the evaluation items, such as performer's indulgence, body language, eye contact, the interaction with the audience, etc. The following ratio distribution is for reference: contents $50 \%$, English skills 30\% and performance 20\%. Participants of the activity, namely the teacher, the performer himself and the peer, are all invited to give an assessment to the performer, according to the score format. Comments of the teacher and 
the peer's can give performer the chance to improve himself in the future. Such activities and evaluation can motivate students to be familiar with and promote Baoding red culture and its English version, which is conducive to the development and international dissemination of Baoding red culture.

\section{Conclusion}

The General Secretary Xi Jinping (2017) once said: "Without full confidence in our culture, without a rich and prosperous culture, the Chinese nation will not be able to rejuvenate itself" (http://www.china.org.cn/20171105-002.pdf). As an advanced culture with Chinese characteristics, red culture should become a solid spiritual support and inexhaustible source of power for young people in the great rejuvenation of the Chinese nation. However, it's a pity to see that the significance of red culture education in college English teaching is undervalued and the problems of teachers' and students' weak political literacy, output motivation deficiency and unscientific evaluation criteria are universal. To solve these problems, both the teachers and students should have a strong awareness of the significance of the red culture heritage. The teachers should encourage the students to produce presentations or dialogues related to the red culture by providing them with simulated scenario and interesting activities. Besides, the evaluation criteria should be redesigned, changing skill-focused and test-oriented evaluation to multiple evaluations which take the moral education and content delivery into account. It is the English teachers' obligation to clearly understand the current situation of the absence of the red culture in College English teaching, and explore effective strategies in teaching practice, are the absolute duty for English teachers. Hopefully, this paper may have some enlightenment for college English teaching with the topic of Baoding red culture.

\section{Acknowledgements}

Baoding Education Science "13th Five-Year-Plan" Subject: Research on the Effectiveness of Baoding Red Culture Thematic Teaching in College English Classes under POA Theory, no. 181082.

Research Topic of Social Science Development in Hebei Province: Research on the Effective Output Strategy of Hebei Red Culture in English Major Teaching, no. Y040120180536.

\section{Conflicts of Interest}

The authors declare no conflicts of interest regarding the publication of this paper.

\section{References}

Ding, Q. (2018). Path Choice of Innovative Red Culture Communication in the New Media Age. News Front, 9, IO6dO7.

Zhao, J. H. (2015). Practice of Using Red Cultural Resources in Ideological and Political 
Teaching in Colleges and Universities. Intelligence, 13, 4.

Tan, X. X. (2014). Research on the Way of Integrating Local Red Cultural Resources into Teaching. New West, 12, 40-41

Huo, Q. S. (2017). Research on the Integration of Red Spirit into College Students' Ideological and Political Education in the Context of New Era. Higher Education Journal, 9, 176-178.

Xi, J. P. (2017). Secure a Decisive Victory in Building a Moderately Prosperous Society in All Respects and Strive for the Great Success of Socialism with Chinese Characteristics for a New Era. Xi Jinping's Report at the 19th National Congress of the Communist Party of China. http://www.china.org.cn/20171105-002.pdf 